\title{
Perancangan dan Implementasi Sistem Pelaporan Monitoring Spektrum Frekuensi Radio
}

\author{
(Design and Implementation of Reporting the Radio Frequency Spectrum Monitoring \\ Systems)
}

\author{
Eet Widarini, I Gede Pasek Suta Wijaya, Andy Hidayat Jatmika \\ Dept Informatics Engineering, Mataram University \\ Jl. Majapahit 62, Mataram, Lombok NTB, INDONESIA \\ Email: iit.widarini4@gmail.com, [gpsutawijaya, andy]@unram.ac.id
}

\begin{abstract}
Radio Frequency Spectrum Monitoring is a unit under the Directorate General of Resources and Equipment of Post and Information Technology, which is on duties to supervise and control the use of the radio frequency spectrum. This includes monitoring activities consisting of frequency band observations, fixed or mobile service radio stations, broadcast radio and broadcast television. Currently, data processing until reporting for monitoring activities is still done manually. Based on these problems, we need a system that can process computerized data in order to obtain information about the deviations. It takes a system that can make reports and recapitulation of monitoring activities per location point, per day, per week, per month, per three months, six months and per year. The system implementation is tested on 6 respondents from employees and 30 from students with an average percentage of $90.65 \%$ indicating that the proposed system has run properly according to user needs.
\end{abstract}

Key words: Monitoring systems, reporting systems, radio frequency spectrum, information systems.

\section{PENDAhUluan}

Spektrum Frekuensi Radio adalah kumpulan dari pita frekuensi radio dan merupakan sumber daya alam yang terbatas. Pita Frekuensi Radio merupakan bagian dari spektrum frekuensi radio yang memiliki lebar tertentu. Frekuensi radio merupakan sumber daya alam yang strategis dan mempunyai nilai ekonomis tinggi, sehingga pemanfaatanya harus tertib dan tunduk terhadap peraturan nasional maupun internasional [1]. Untuk dapat menggunakan spektrum frekuensi radio, harus memiliki Izin Stasiun Radio (ISR).

Loka Monitor Spektrum Frekuensi Radio Mataram adalah Unit Pelaksana Teknis yang berada di lingkungan Direktorat Jenderal Sumber Daya dan Pos dan Informatika. Unit ini bertugas melaksanakan pengawasan dan pengendalian di bidang penggunaan spektrum frekuensi radio. Hal ini meliputi kegiatan monitoring yang terdiri dari observasi pita frekuensi, monitoring radio dinas tetap/bergerak, radio siaran dan televisi siaran [2]. Saat ini, Pengolahan data sampai pelaporan untuk kegiatan monitoring masih dilakukan secara manual. Untuk mencari adanya penyimpangan-penyimpangan baik penyimpangan center frequency, bandwidth maupun mencari legalitas dari suatu stasiun maka harus dianalisa satu per-satu. Untuk mengetahui range pita frekuensi dan alokasi RR dari suatu frekuensi maka harus mencari datadata tersebut pada tabel alokasi frekuensi radio Indonesia sesuai dengan Peraturan Menteri Komunikasi dan Informatika Republik Indonesia Nomor 25 Tahun 2014 Tentang Tabel Alokasi Spektrum Frekuensi Radio Indonesia. Kemudian untuk mengetahui kanal TV dan kanal FM dari suatu frekuensi maka harus mencari datadata tersebut di masterplan kanal TV dan masterplan kanal FM. Sedangkan untuk pembuatan rekapitulasi data-data monitoring yang telah diolah, dengan frekuensi sesuai database dan tidak sesuai database masing-masing akan di akumulasi lalu akan disortir untuk dijadikan rekapitulasi. Begitu juga dengan pembuatan laporan datadata monitoring yang telah diolah akan disortir, selanjutnya akan di pindahkan ke format ROL (Report Online) sebagai laporan ke kantor pusat.

Oleh karena itu, dibutuhkan suatu sistem yang dapat mengolah data secara terkomputerisasi guna mendapatkan informasi mengenai adanya penyimpangan-penyimpangan maupun legalitas dari suatu stasiun. Dan dibutuhkan suatu sistem yang dapat membuat pelaporan serta rekapitulasi kegiatan monitoring dari pertitik lokasi, per-hari, perminggu, per-bulan, per-tiga bulan, per-enam bulan dan pertahun. Sistem ini dibangun menggunakan web based, karena untuk mengolah data hasil kegiatan monitoring komputasi tidak terlalu rumit dan tidak membutuhkan resource yang tinggi dalam pengaplikasiannya.

\section{PENELITIAN SEBELUMNYA}

Penelitian terkait sistem monitoring yang telah dilakukan pada [3] menghasilkan sistem informasi yang dapat mempercepat dan mempermudah dalam proses penyampaian dan penerimaan laporan, dan memaksimalkan akurasi laporan. Sistem monitoring juga dapat memudahkan dalam menganalisis data pelaporan dan dapat meminimalisir pemborosan kertas yang digunakan untuk pelaporan [4]. Penelitian yang dilakukan pada [5] mengatakan bahwa dengan menggunakan sistem komputerisasi maka permasalahan yang ditangani secara manual dapat ditangani lebih cepat walaupun data yang ditangani sangat banyak dan cukup kompleks. Penggunaan 
sistem informasi juga telah terbukti mampu menyelesaikan permasalahan administrasi pada suatu organisasi [6].

\section{Metode Usulan}

Berikut merupakan diagram alir dari proses pembuatan sistem pelaporan monitoring spektrum frekuensi radio. Dapat dilihat pada Gambar 1.

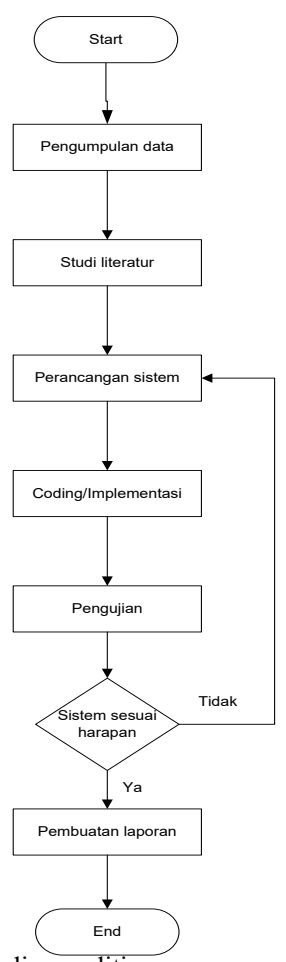

Gambar 1. Diagram alir penelitian

\section{A. Pengumpulan Data}

Pengumpulan data dilakukan dengan beberapa metode, diantaranya:

1. Metode Wawancara

Pada metode wawancara penulis menggali informasi mengenai kondisi sistem pelaporan monitoring yang digunakan saat ini dan informasi mengenai sistem yang diharapkan. Selain itu, penulis mengumpulkan data-data yang dibutuhkan dalam pembangunan sistem berupa data perizinan, data masterplan kanal, data alokasi frekuensi radio, data kelas emisi dan data kelas stasiun.

2. Metode Observasi

Pada metode observasi penulis melakukan pengamatan secara langsung terhadap sistem pelaporan monitoring yang digunakan saat ini.

\section{B. Studi Literatur}

Studi literatur yang dilakukan dalam pembuatan tugas akhir ini adalah mempelajari dan memahami literatur yang berkaitan dengan penelitian yang dilakukan. Seperti memahami syarat-syarat penyimpangan suatu frekuensi. Mempelajari framework Codeigniter dan twitter bootstrap yang digunakan dalam pembangunan sistem-nya.

\section{Perancangan Sistem}

Penggambaran perancangan sistem yang digunakan adalah use case diagram, class diagram, Sequence Diagram, entity relationship diagram dan activity diagram.

\section{Coding/Implementasi}

Hasil perancangan sistem diterjemahkan ke dalam kode-kode dengan menggunakan bahasa pemrograman yang telah ditentukan. Pembuatan sistem pelaporan monitoring spektrum frekuensi radio menggunakan codeigniter sebagai framework-nya.

\section{E. Pengujian}

Setelah tahap coding dan implementasi selesai, maka tahap selanjutnya adalah melakukan pengujian terhadap sistem. Pengujian dilakukan dengan menguji tiap operasi pada sistem untuk mengetahui apakah sistem sudah berjalan dengan baik atau tidak. Pengujian yang dilakukan meliputi verifikasi dan validasi. Verifikasi dilakukan dengan melakukan uji coba program pada sistem pelaporan monitoring spektrum frekuensi radio yang telah dibuat. Sedangkan Validasi dilakukan dengan menggunakan kuisioner dan mencari 6 orang responden dari pegawai dan 30 responden dari mahasiswa untuk mencoba sistem secara langsung.

\section{IMPLEMENTASI SISTEM}

Implementasi sistem pelaporan monitoring spektrum frekuensi radio menggunakan framework codeigniter dengan bahasa pemrograman PHP dan HTML, MySql sebagai server database-nya serta wamp server sebagai server local-nya. Berikut merupakan langkah mengolah data hasil kegiatan monitoring dalam hal ini adalah pengukuran radio siaranpada sistem pelaporan monitoring spektrum frekuensi radio. Saat sistem mulai dijalankan, maka akan tampilkan halaman login seperti pada Gambar 2 .

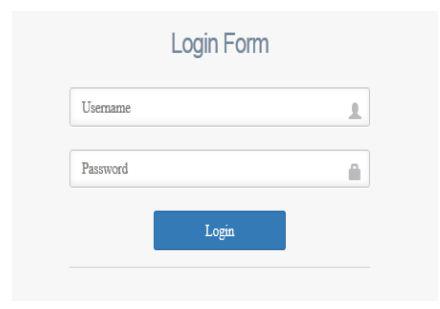

Gambar 2. Halaman login

Pada halaman login user diminta untuk memasukkan username dan password. proses validasi dilakukan dengan memeriksa apakah username dan password sudah cocok dengan data dalam database seperti pada Gambar 2. Jika validasi berhasil, user akan langsung diarahkan ke halaman home. Selanjutnya pilih menu pengukuran radio siaran (Peradsi) lalu pilih tambah data keterangan PeRadSi.

Halaman tambah keterangan PeRadSi digunakan untuk mengisi data keterangan PeRadSi berupa UPT, lokasi, provinsi, kabupaten, kecamatan, jenis stasiun monitor, LS, BT, ketinggian, radio siaran dan tanggal kegiatan. Untuk 
melakukan pengisian data keterangan maka harus mengisi semua data tersebut setelah itu klik tombol submit untuk menyimpannya. Lebih jelasnya dapat dilihat pada Gambar 3.

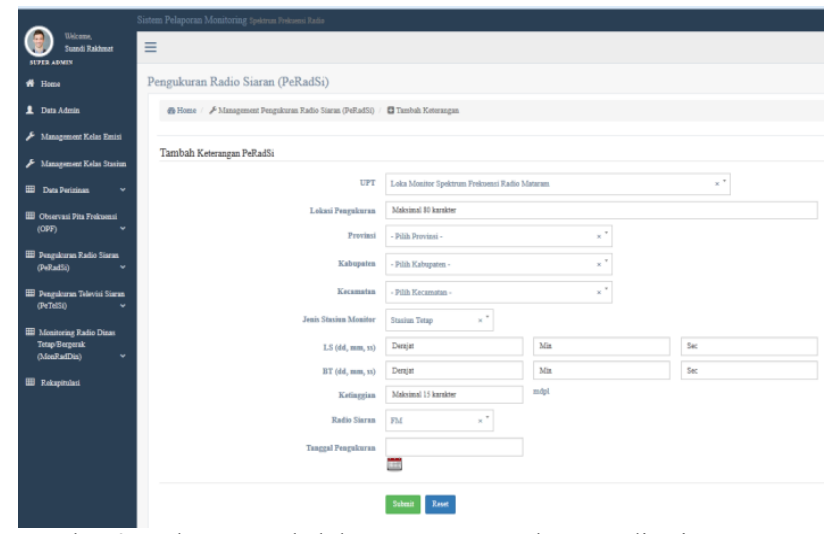

Gambar 3. Halaman tambah keterangan pengukuran radio siaran

Setelah data dimasukkan maka user akan diarahkan ke halaman data keterangan pengukuran radio siaran. Halaman ini digunakan untuk menampilkan data keterangan PeRadSi yang telah dimasukkan atau ditambahkan sebelumnya pada halaman tambah keterangan PeRadSi. Terdapat pula tombol yang digunakan untuk merubah keterangan PeRadSi, menghapus keterangan PeRadSi, menambah data PeRadSi dan melihat data PeRadSi. Lebih jelasnya dapat dilihat pada Gambar 4.

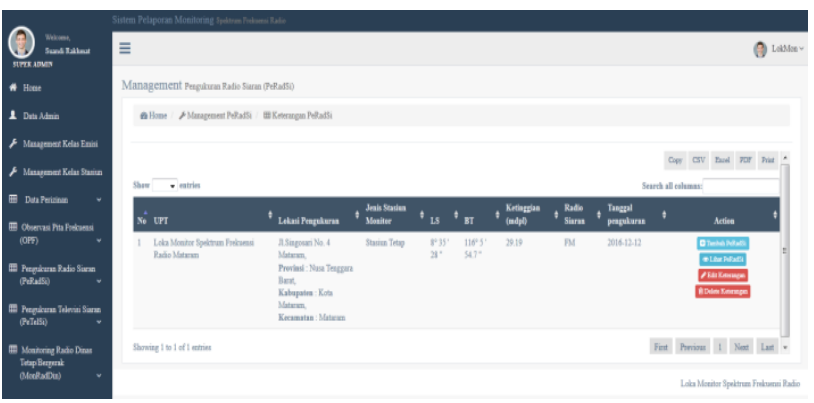

Gambar 4. Halaman data keterangan pengukuran radio siaran

Selanjutnya pilih tombol tambah PeRadSi untuk melakukan pengolahan data PeRadSi. Lebih jelasnya dapat dilihat pada Gambar 5.
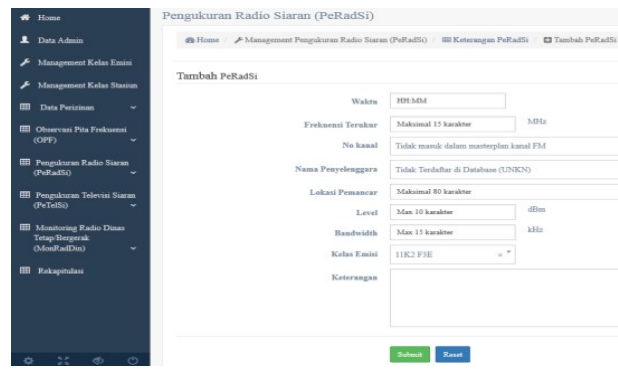

Gambar 5. Halaman tambah data pengukuran radio siaran
Kemudian setelah data dimasukkan dan untuk melihat hasil data yang telah diolah maka user dapat memilih tombol lihat data PeRadSi pada halaman data keterangan PeRadSi. Lebih jelasnya dapat dilihat pada Gambar 6 . Terdapat pula form untuk pengisian catatan, dalam hal ini catatan sudah terisi. Jika data catatan ingin dirubah maka user dapat menekan tombol edit pada tabel catatan.

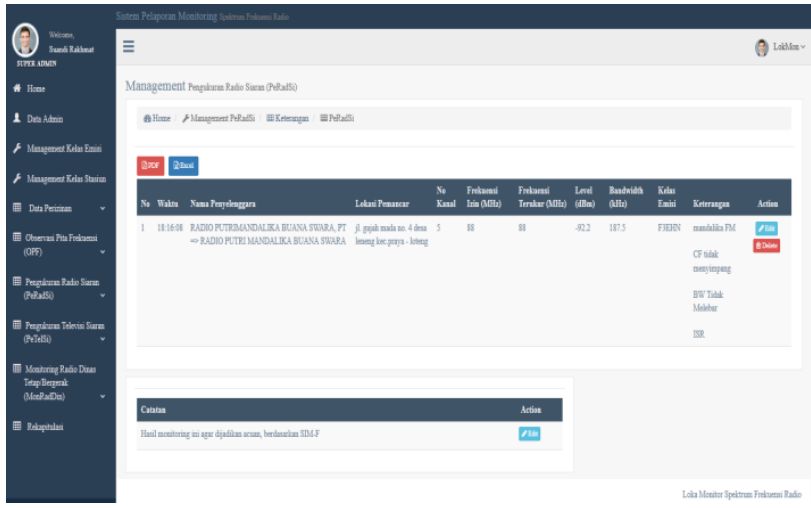

Gambar 6. Halaman data pengukuran radio siaran.

Untuk dapat membuat laporan maka harus memilih bulan dan tahun untuk laporan bulanan, kemudian pilih tipe file berupa *.pdf dan *.xls lalu klik tombol enter. Lebih jelasnya dapat dilihat pada Gambar 7 Gambar 8 merupakan tampilan laporan PeRadSi untuk laporan bulanan dengan tipe file *.xls. Sedangkan Gambar 9 merupakan tampilan laporan PeRadSi untuk laporan bulanan dengan tipe file *.pdf.

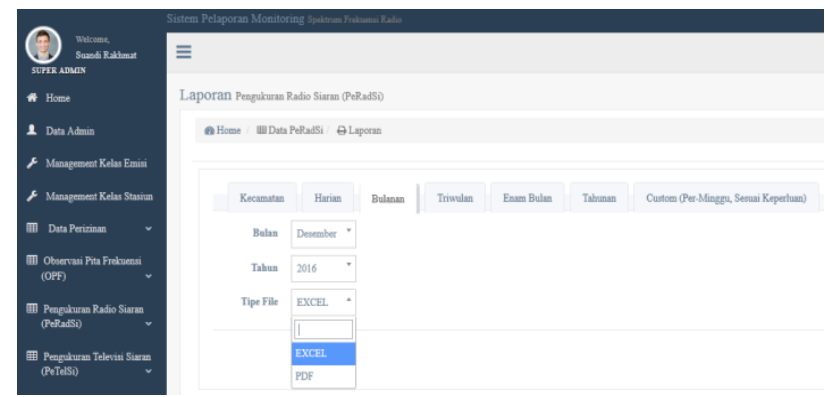

Gambar 7. Halaman laporan pengukuran radio siaran

KEMENTERIAN KOMUNIIASI DAN INEFRMATIKA
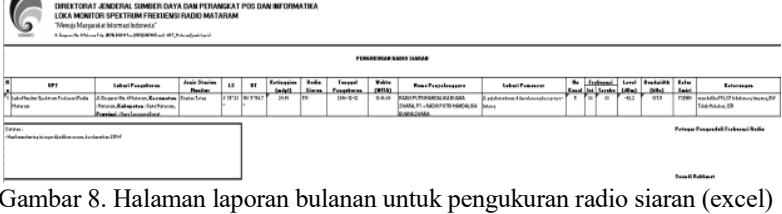

Gambar 8. Halaman laporan bulanan untuk pengukuran radio siaran (excel)

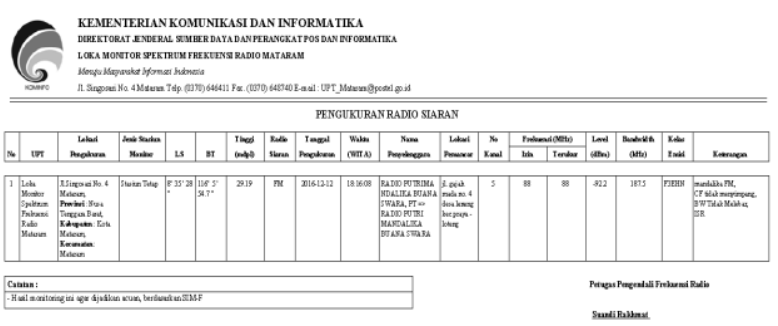

Gambar 9. Halaman laporan bulanan untuk pengukuran radio siaran (pdf) 


\section{V.HASIL PENGUJIAN DAN DISKUSI}

Setelah melakukan pengimplementasian sistem maka selanjutnya yang dilakukan adalah pengujian sistem. Pengujian dilakukan meliputi pengujian blackbox dan pengujian oleh responden.

\section{A. Pengujian Black Box}

Pada bagian ini akan dijelaskan pengujian halaman login super admin, pengujian mengelola data pengukuran radio siaran (PeRadSi), pengujian membuat laporan pengukuran radio siaran (PeRadSi), dan pengujian data monitoring radio dinas tetap / bergerak (MonRadDin).

\section{A.1. Pengujian halaman login Super Admin}

Super admin terlebih dahulu harus login ke sistem dengan data masukan seperti username "super admin" dan password "admin". Namun ternyata password yang dimasukkan salah, lalu sistem akan memberikan pesan kesalahan dan tetap berada pada halaman form login (dapat dilihat pada Gambar 10). Kemudian super admin memasukkan kembali username "super admin" dan password " ". Karna password-nya kosong sistem akan memberikan pesan kesalahan dan tetap berada pada form login tersebut sampai username dan password yang dimasukkan benar. Seperti, username "super admin" dan password "super admin". Kemudian super admin akan diarahkan ke halaman home super admin. Gambar 11 merupakan tampilan apabila password kosong dan Gambar 12 merupakan tampilan jika login benar.

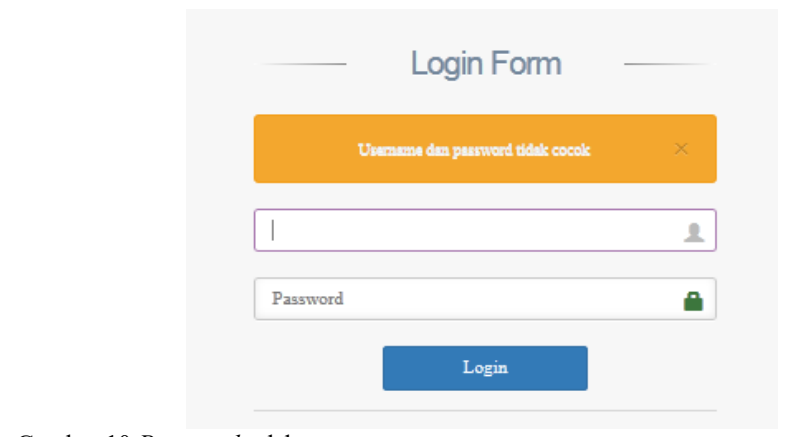

Gambar 10 Password salah

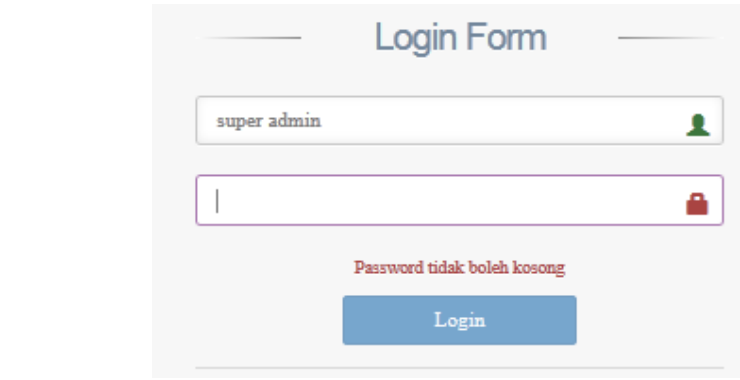

Gambar 11 Password kosong.

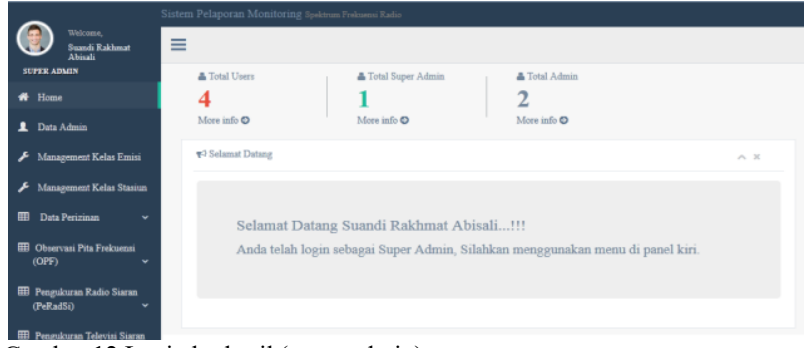

Gambar 12 Login berhasil (super admin).

\section{A.2. Pengujian mengelola data pengukuran radio siaran (PeRadSi)}

Super admin harus mengisi data keterangan terlebih dahulu sebelum mengisi atau menambahkan data-data pengukuran radio siaran. Pengisian data keterangan dapat dilakukan di halaman tambah keterangan PerRadSi dengan mengisi data-data seperti upt "Loka Monitor Spektrum Frekuensi Radio Mataram", provinsi "Nusa Tenggara Barat", kabupaten "kota mataram", kecamatan "mataram", lokasi "jln. Singosari no. 4 mataram", jenis stasiun monitor "stasiun tetap", LS "30 15 35", BT "116 5 54.7", tinggi "29.19", radio siaran "FM" dan tanggal "2016-12-12" lalu tekan tombol submit (dapat dilihat pada Gambar 13) kemudian akan dirahkan ke halaman data keterangan PeRadSi (dapat dilihat pada Gambar 14). Setelah data tersimpan, ternyata data ketinggian yang diisi sebelumnya salah yaitu "29". Untuk dapat memperbaikinya, super admin dapat menekan tombol edit pada halaman data keterangan pengukuran radio siaran kemudian akan diarahkan ke halaman update data keterangan dan dapat merubah data dari "29" menjadi "29.19" (dapat dilihat pada Gambar 15) lalu tekan submit setelah itu akan diarahkan ke halaman data keterangan PeRadSi (dapat dilihat pada Gambar 16).

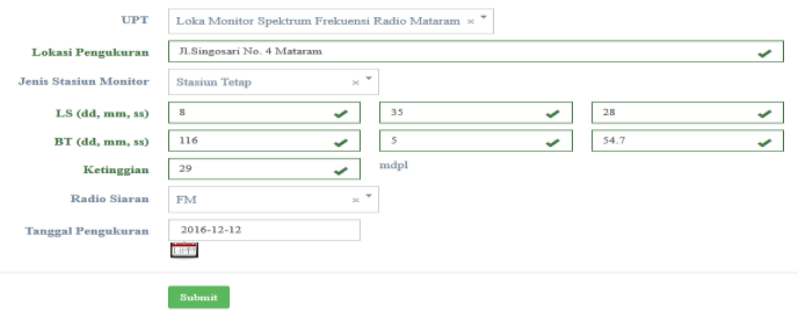

Gambar 13 Penambahan data keterangan PeRadSi

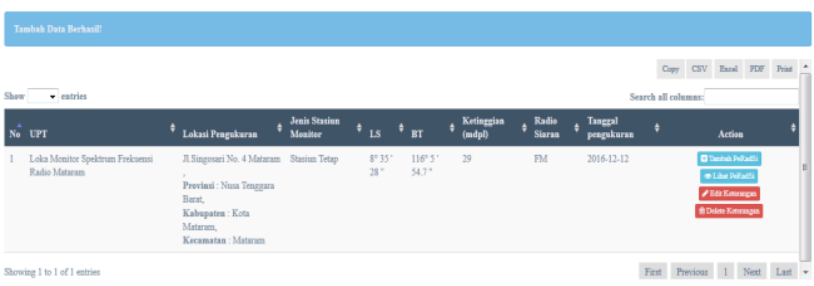

Gambar 14 Data keterangan PeRadSi setelah penambahan data. 


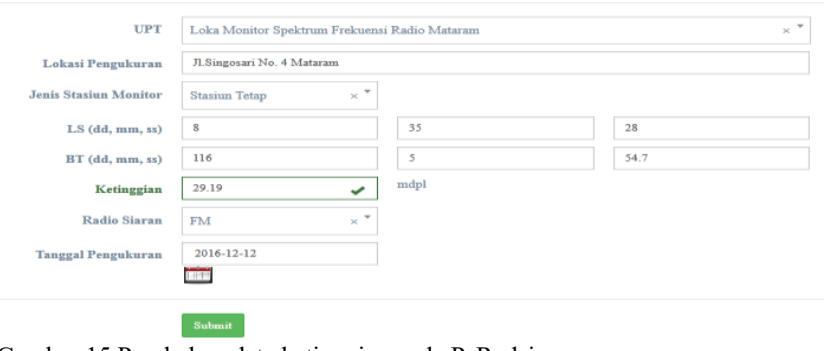

Gambar 15 Perubahan data ketinggian pada PeRadsi.

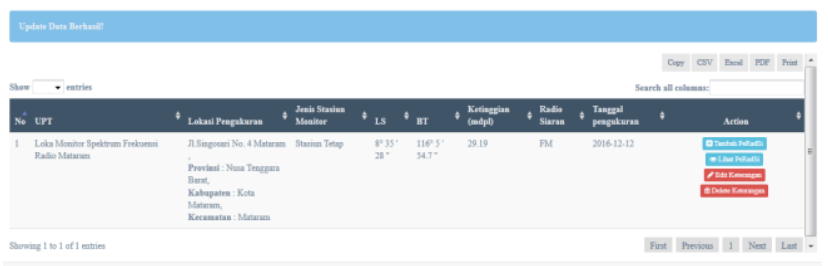

Gambar 16 Tampilan data keterangan PeRadSi setelah perubahan data.

Setelah mengisi keterangan PeRadSi selanjutnya menambahkan data-data PeRadSi dengan menekan tombol tambah PeRadSi pada halaman data pengukuran radio siaran adapun data-datanya seperti waktu "18:16", frekuensi terukur "88", no kanal "5", nama penyelenggara "radio putri mandalika buana swara", lokasi pemancar "jl. gajah mada no. 4 desa leneng kec.praya - loteng", level "92.2", bandwidth "187.5", kelas emisi "F3EHN" dan keterangan"-" setelah data diisi lalu tekan submit (dapat dilihat pada Gambar 17). Jika berhasil maka super admin tetap berada pada halaman tersebut dan terdapat notifikasi yang memberikan informasi bahwa data berhasil ditambah (dapat dilihat pada Gambar 18). Setelah ditambahkan, super admin dapat melihatnya pada tabel data pengukuran radio siaran. Terdapat beberapa field yang otomatis muncul seperti frekuensi izin, status central frequency, status legalitas, status bandwidth dan keterangan status namun pada skenario ini keterangan status tidak muncul karena masa berlaku untuk frekuensi " 88 " yang terdapat pada data perizinan masih berlaku (dapat dilihat pada Gambar 19). Apabila super admin ingin merubah data keterangan dari "-" menjadi "mandalika FM" maka super admin dapat menekan tombol edit pada halaman data PeRadSi dan melakukan perubahan tersebut lalu tekan submit (dapat dilihat pada Gambar 20). Jika berhasil maka akan dirujuk ke halaman data PeRadSi (dapat dilihat pada Gambar 21). Apabila form data frekuensi terukur "88ui", level "$92.2 \mathrm{p}$ " dan bandwidth " $187.5 \mathrm{j}$ " maka sistem akan memberikan pesan kesalahan untuk memperbaiki format penulisan data. Format dari form level hanya boleh diisi dengan bilangan rasional kemudian untuk format frekuensi terukur dan bandwidth hanya bisa diisi dengan angka serta titik (dapat dilihat pada Gambar 22).

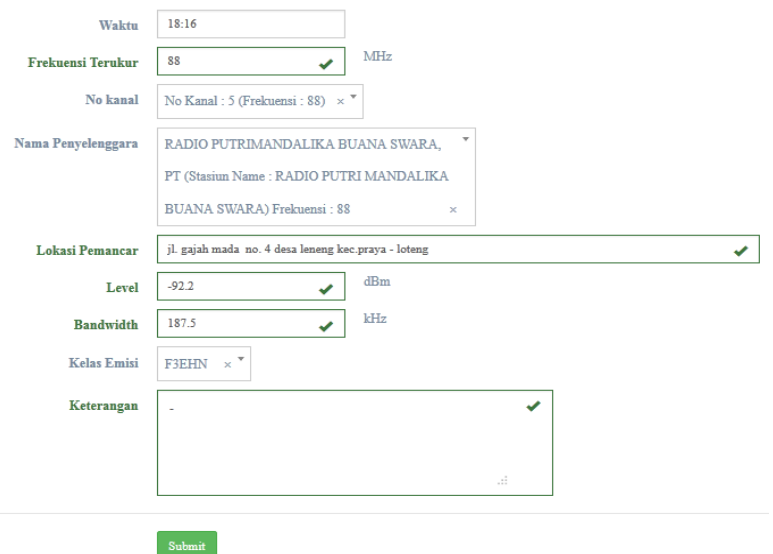

Gambar 17 Penambahan data PeRadSi.

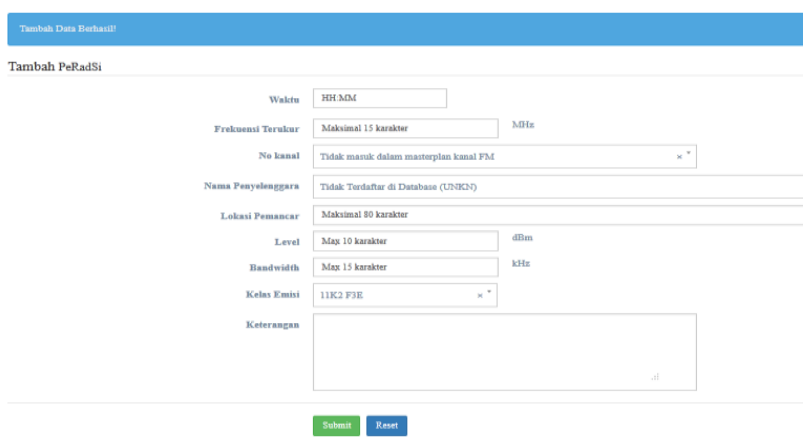

Gambar 18 Tampilan penambahan data PeRadSi sukses.

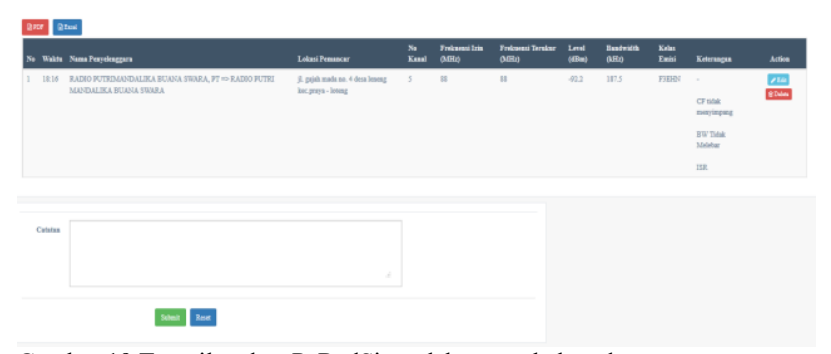

Gambar 19 Tampilan data PeRadSi setelah penambahan data.

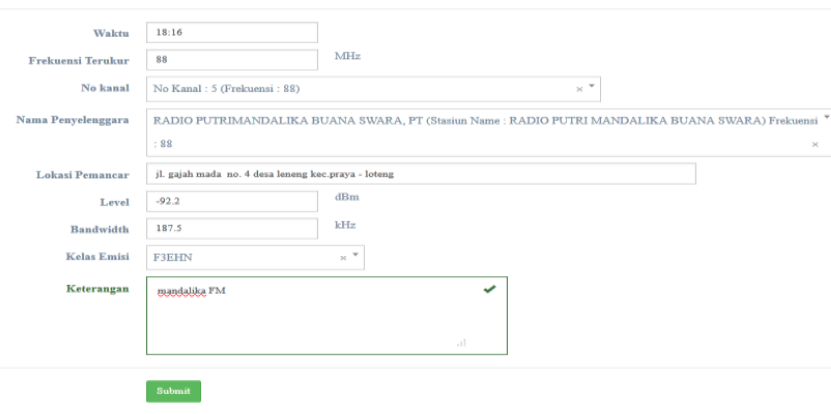

Gambar 20 Perubahan data keterangan PeRadSi 


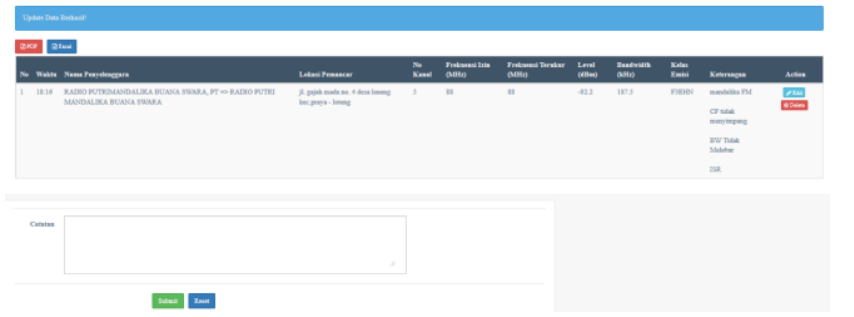

Gambar 21 Tampilan data PeRadSi setelah perubahan data.

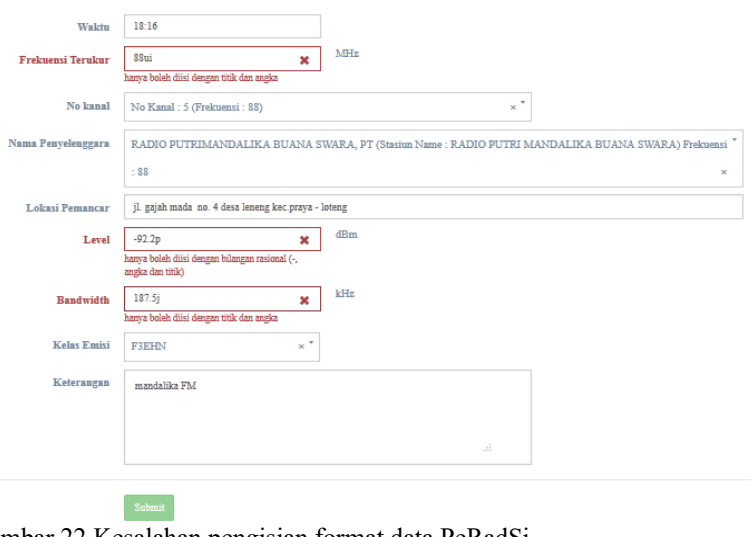

Gambar 22 Kesalahan pengisian format data PeRadSi.

Setelah data keterangan PeRadSi dan data PeRadSi ditambahkan maka selanjutnya yaitu mengisi catatan PeRadSi pada halaman data PeRadSi seperti "hasil monitoring ini agar dijadikan acuan" (dapat dilihat pada Gambar 23). Jika berhasil maka akan diarahkan ke halaman data PeRadSi (dapat dilihat pada Gambar 24). Kemudian, apabila ingin menambah atau ingin merubah catatan dapat langsung menekan tombol edit pada tabel catatan lalu ubah data atau tambah data sesuai keperluan seperti, super admin ingin menambah catatan "Berdasarkan SIM-F" (dapat dilihat pada Gambar 25). Sedangkan hasilnya dapat dilihat pada Gambar 26.

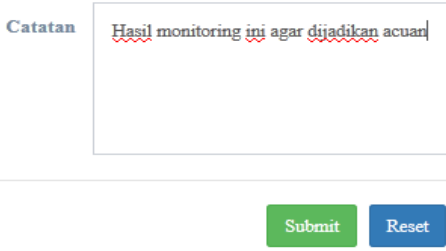

Gambar 23 Pengisian catatan PeRadSi.

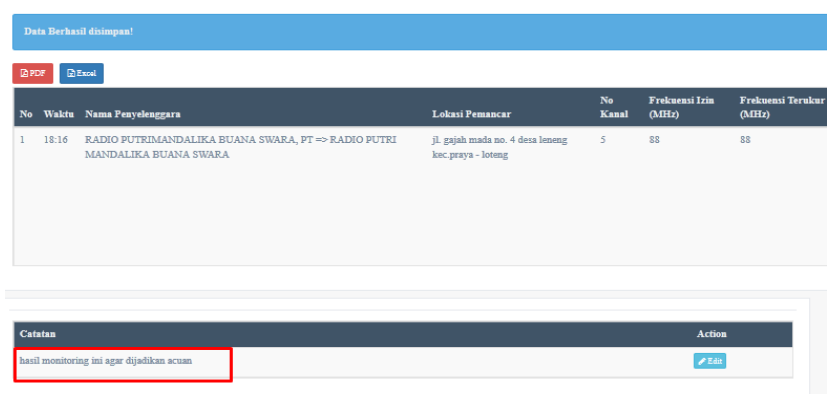

Gambar 24 Tampilan setelah pengisian catatan PeRadSi.
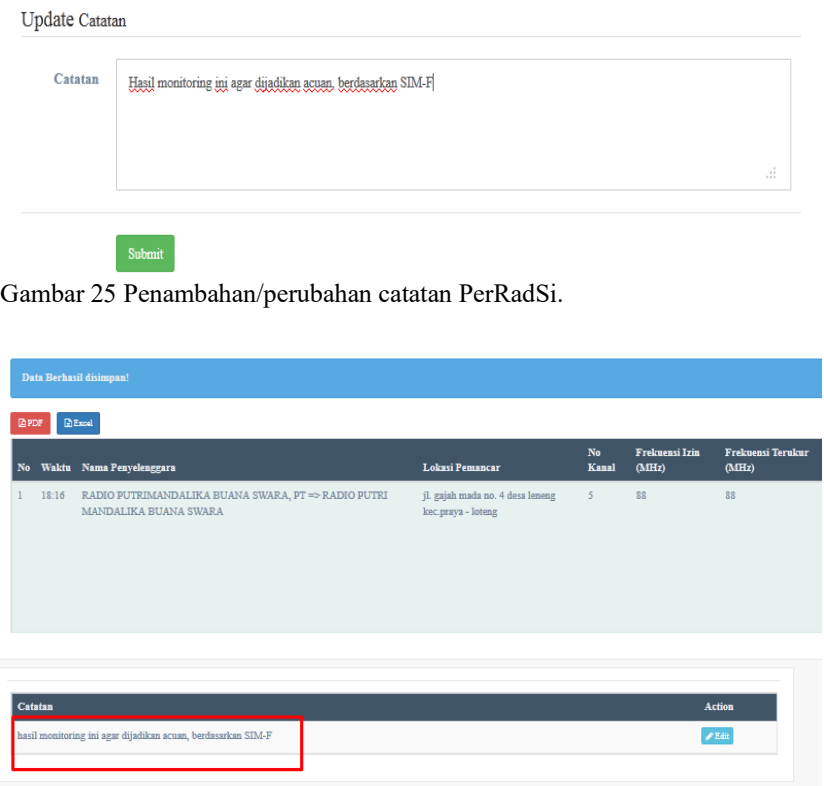

Gambar 26 Tampilan setelah penambahan/perubahan catatan PeRadSi.

\section{A.3. Pengujian membuat laporan pengukuran radio siaran (PeRadSi)}

Hasil dari pengolahan data pengukuran radio siaran dapat dijadikan sebagai bahan pelaporan meliputi: laporan pertitik lokasi, laporan perkecamatan, laporan perhari, laporan perbulan, laporan pertiga bulan, laporan perenam bulan, laporan pertahun dan custom (sesuai keperluan).

- Hasil pembuatan laporan bulanan dapat dilihat pada Gambar 27. Laporan ini berdasarkan bulan, tahun dan tipe file. Seperti bulan "desember", tahun "2016" dan tipe file "excel" lalu tekan enter.

- Hasil pembuatan laporan triwulan dapat dilihat pada Gambar 28. Laporan ini berdasarkan bulan, tahun dan tipe file. Seperti bulan "Oktober-desember", tahun"2016" dan tipe file "PDF" lalu tekan enter.

KEMENTERIAN KOMUNIIASI DAN INFORMATIKA
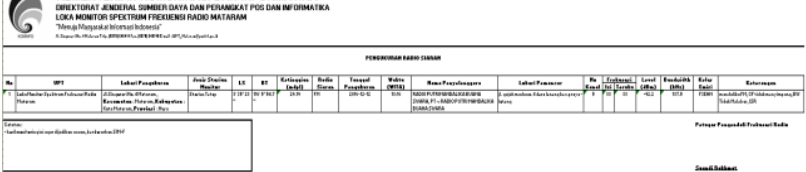

Gambar 27 Laporan bulanan PeRadSi (excel).

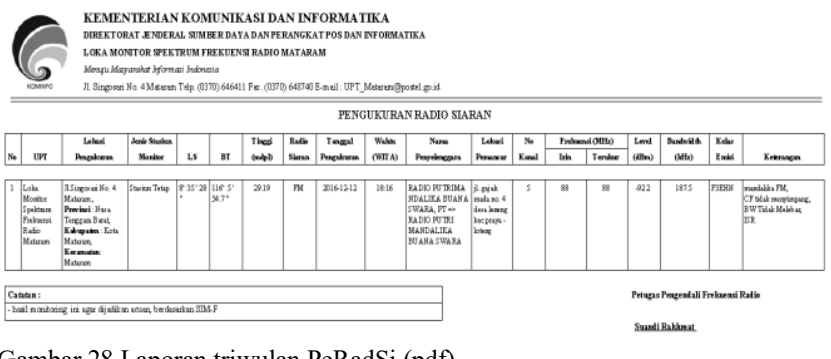

Gambar 28 Laporan triwulan PeRadSi (pdf). 


\section{A.4. Pengujian data monitoring radio dinas tetap / bergerak (MonRadDin)}

Untuk dapat mengolah data monitoring radio dinas tetap / bergerak, super admin terlebih dahulu mengisi data keterangan MonRadDin pada halaman tambah keterangan MonRadDin seperti upt "Loka Monitor Spektrum Frekuensi Radio Mataram", lokasi "jln. Singosari no. 4 mataram", provinsi "nusa tenggara barat", kabupaten "kota mataram", kecamatan "mataram", jenis stasiun monitor "stasiun tetap", LS "08 35 28", BT "116 5 54.7", tinggi "29.12", kelas stasiun "tetap darat" dan tanggal "2016-11-23" lalu tekan tombol submit (dapat dilihat pada Gambar 29). Jika berhasil maka super admin akan diarahkan ke halaman data keterangan MonRadDin (dapat dilihat pada Gambar 30). Kemudian, apabila terdapat penulisan yang salah terhadap data yang telah tersimpan, maka super admin dapat melakukan perubahan data dengan menekan tombol edit pada halaman data keterangan MonRadDin seperti, tinggi "29" diubah menjadi "29.19" (dapat dilihat pada Gambar 31) lalu tekan submit dan akan diarahkan ke halaman data keterangan MonRadDin jika edit data berhasil (dapat dilihat pada Gambar 32).

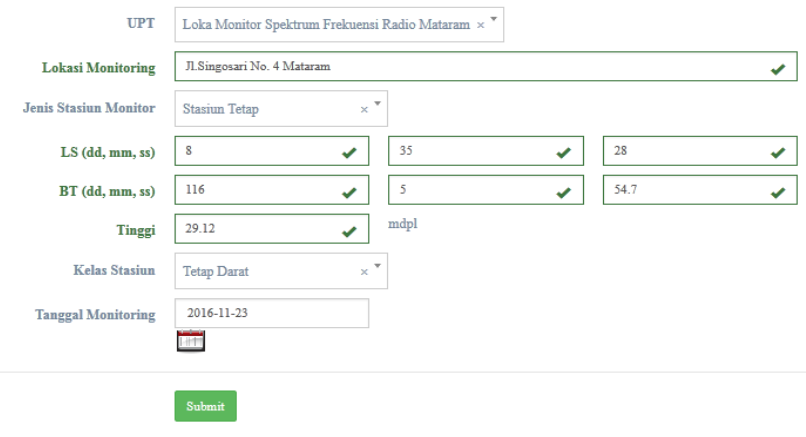

Gambar 29 Penambahan data keterangan MonRadDin.

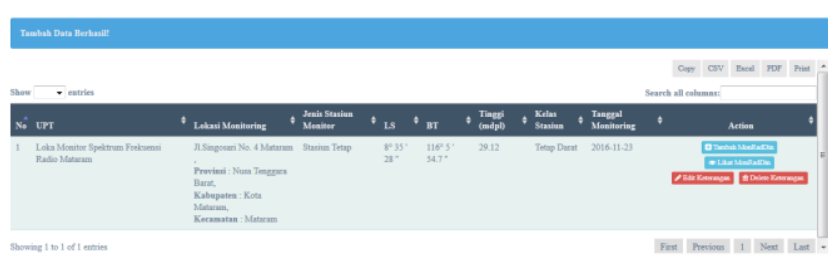

Gambar 30 Tampilan data keterangan MonRadDin setelah penambahan data.

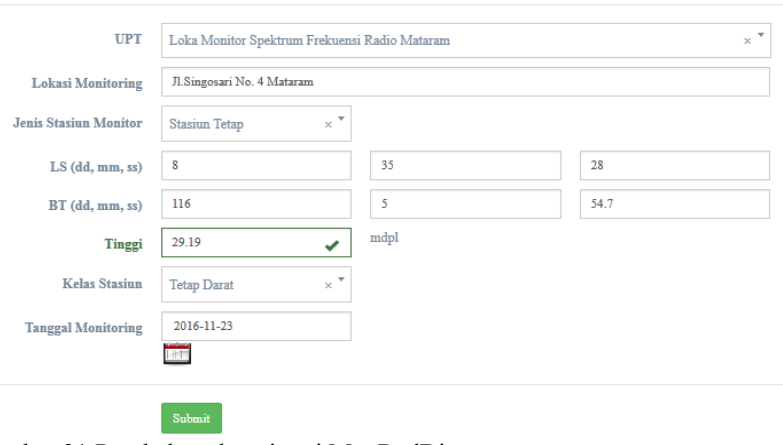

Gambar 31 Perubahan data tinggi MonRadDin.

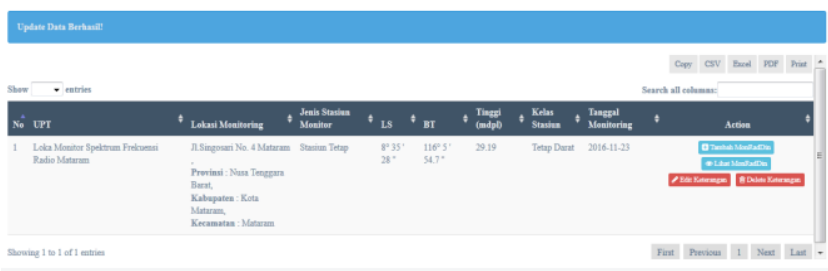

Gambar 32 Tampilan data keterangan MonRadDin setelah perubahan data.

Setelah mengisi keterangan MonRadDin selanjutnya menambahkan data-data MonRadDin dengan menekan tombol tambah MonRadDin pada halaman data MonRadDin adapun data-datanya seperti waktu "19:27", frekuensi TX "342.675”, frekuensi masterplan " 342.675 ”, level terukur "-70.69", frekuensi RX "0", nama penyelenggara "PT.PLN (persero) Wil. NTB", lokasi pemancar "Jl. Arya Banjar Getas Tanjung Karang- Kota Mataram", bandwidth "24", kelas emisi "F3E", bandwidth "24", kualitas "4" dan keterangan" tone kontinyu" setelah data diisi lalu tekan submit (dapat dilihat pada Gambar 33). Jika berhasil maka super admin tetap berada pada halaman tersebut dan terdapat notifikasi yang memberikan informasi bahwa data berhasil ditambah (dapat dilihat pada Gambar 34). Setelah ditambahkan, super admin dapat melihatnya pada tabel data MonRadDin. Terdapat beberapa field yang otomatis muncul seperti status legalitas dan keterangan status (dapat dilihat pada Gambar 35). Setelah data tersimpan, ternyata kelas stasiun yang diisi sebelumnya salah yaitu "AL" dan akan dirubah ke "BC" maka super admin dapat menekan tombol edit pada halaman data MonRadDin kemudian melakukan perubahan tersebut lalu tekan submit (dapat dilihat pada Gambar 36). Jika berhasil maka akan dirujuk ke halaman data MonRadDin (dapat dilihat pada Gambar 37). Apabila

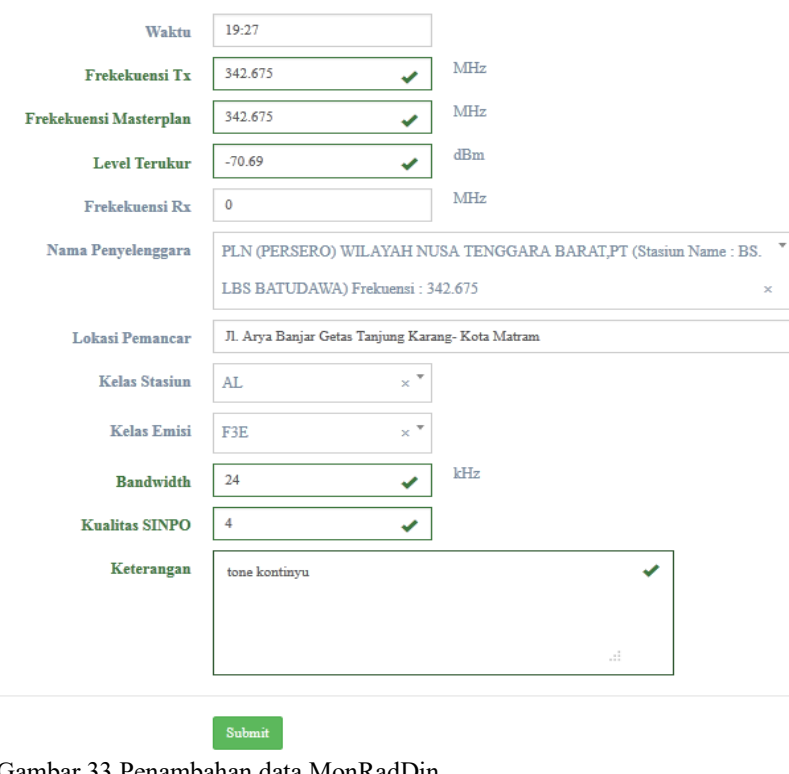

Gambar 33 Penambahan data MonRadDin . 


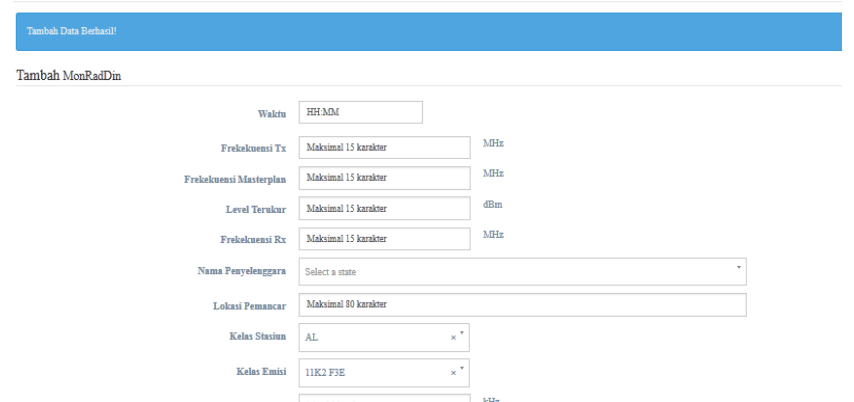

Gambar 34 Tampilan penambahan data MonRadDin sukses.

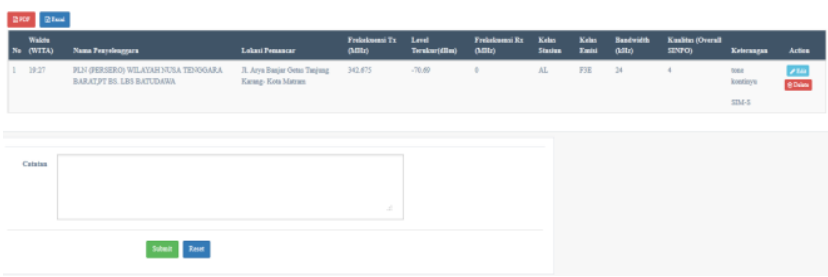

Gambar 35 Tampilan data MonRadDin setelah penambahan data.

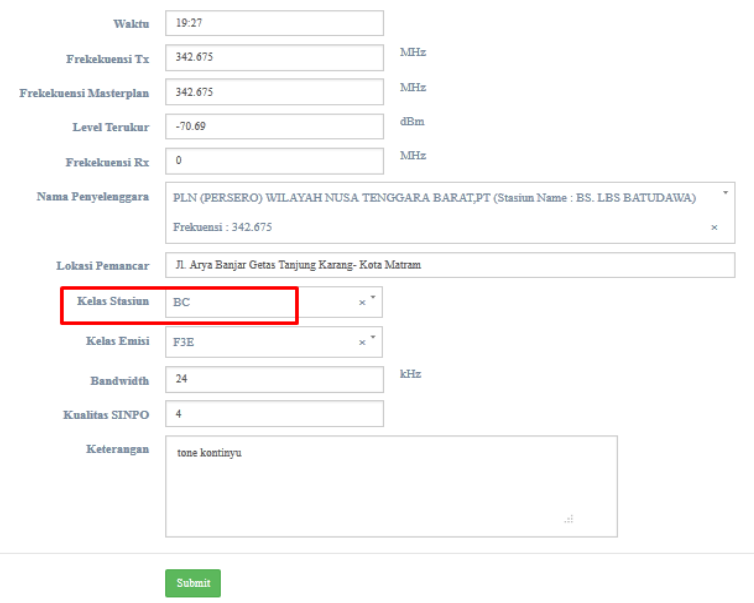

Gambar 36 Perubahan data kelas stasiun MonRadDin.

form data Frekuensi Tx "kl", Frekuensi masterplan "a5", level terukur "a", frekuensi rx "=", bandwidth "l;", kualitas sinpo "k" maka sistem akan memberikan pesan kesalahan untuk memperbaiki format penulisan data. Format dari form kualitas sinpo yaitu kualitas sinpo hanya dapat diisi dengan angka, format dari form level monraddin hanya boleh diisi dengan bilangan rasional kemudian untuk format frekuensi tx, frekuensi rx dan bandwidth hanya bisa diisi dengan angka serta titik (dapat dilihat pada Gambar $38)$.

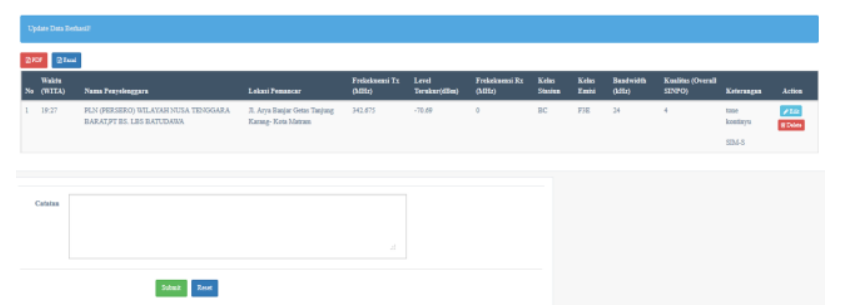

Gambar 37 Tampilan data MonRadDin setelah perubahan data.

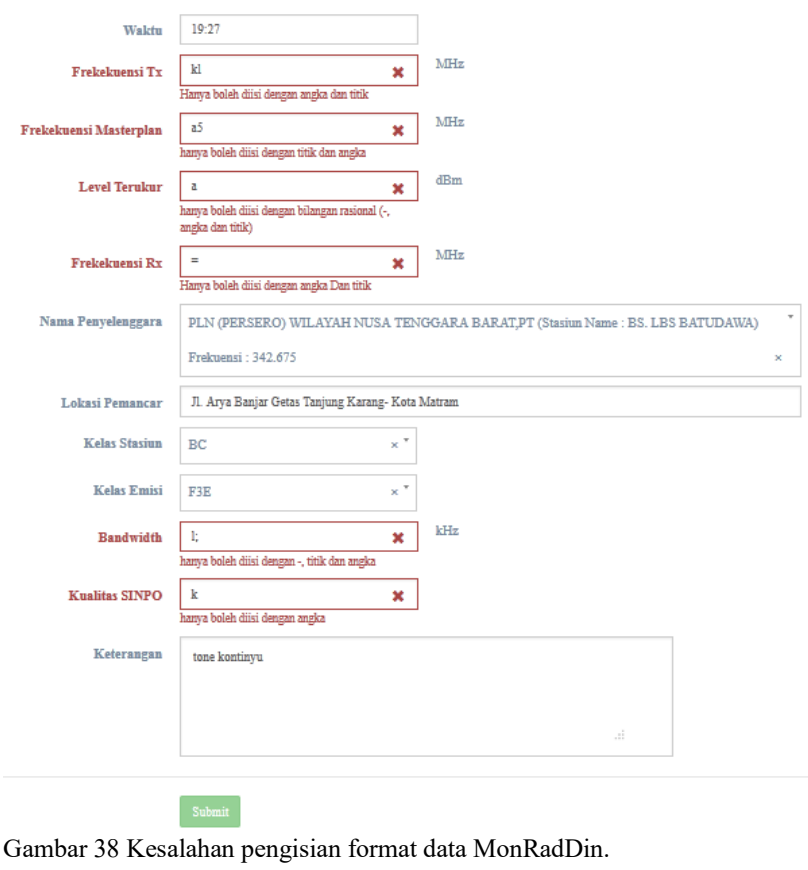

Selanjutnya melakukan pengisian catatan pada form catatan di halaman data MonRadDin seperti catatan "berdasarkan SIM-F" lalu tekan submit (dapat dilihat pada Gambar 39). Jika berhasil maka akan diarahkan ke halaman data MonRadDin (dapat dilihat pada Gambar 40). Kemudian, apabila ingin menambah atau ingin merubah catatan dapat langsung menekan tombol edit lalu ubah data atau tambah data sesuai keperluan seperti, super admin ingin menambah catatan "dijadikan acuan" (dapat dilihat pada Gambar 41). Sedangkan hasilnya dapat dilihat pada Gambar 42.

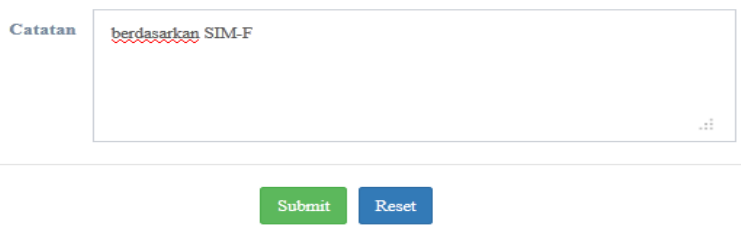

Gambar 39. Pengisian catatan MonRadDin.

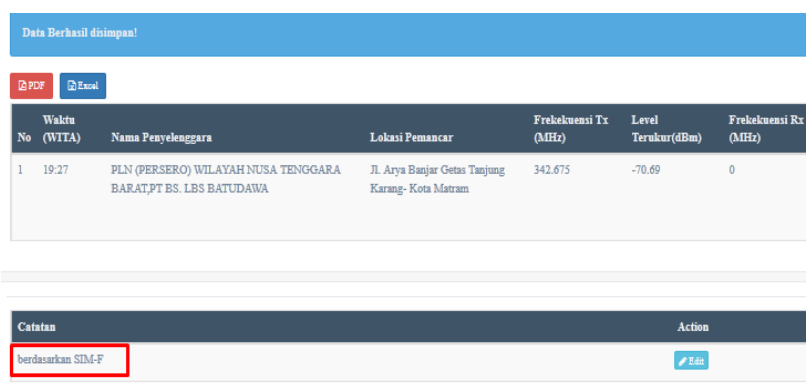

Gambar 40 Tampilan setelah pengisian catatan MonRadDin. 
Update Catatan

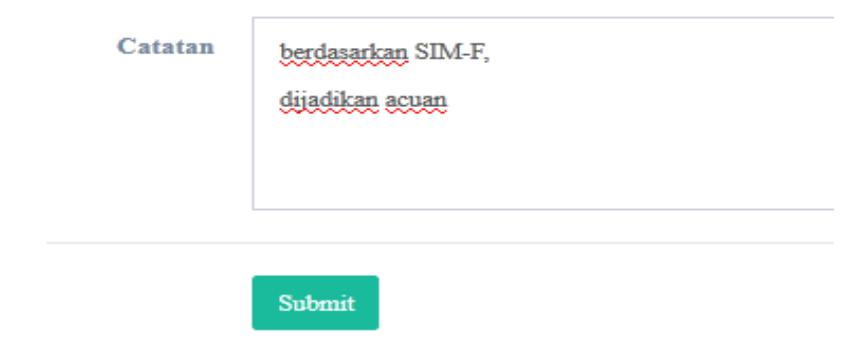

Gambar 41. Penambahan/perubahan catatan MonRadDin.

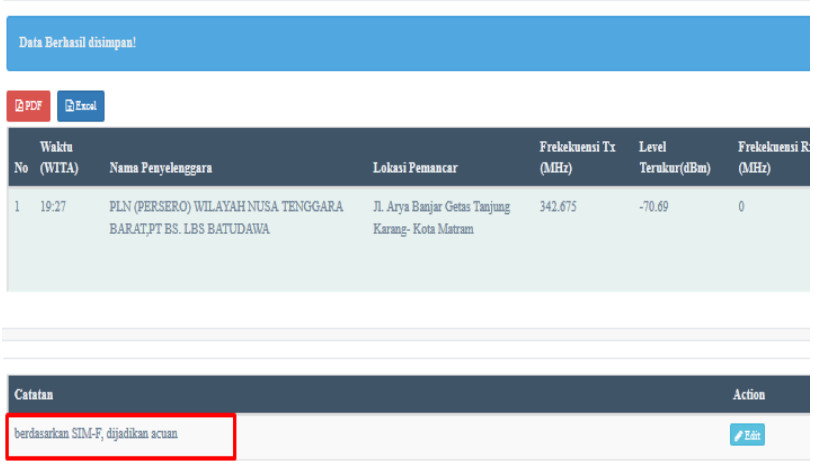

Gambar 42. Tampilan setelah penambahan/perubahan catatan MonRadDin.

\section{B. Pengujian oleh Responden}

Berikut merupakan hasil pengujian dari 6 orang responden pegawai dan 30 orang responden mahasiswa. Berikut perbandingan akumulai persentase jawaban dari pegawai dengan mahasiswa. Dapat dilihat pada Gambar 43.

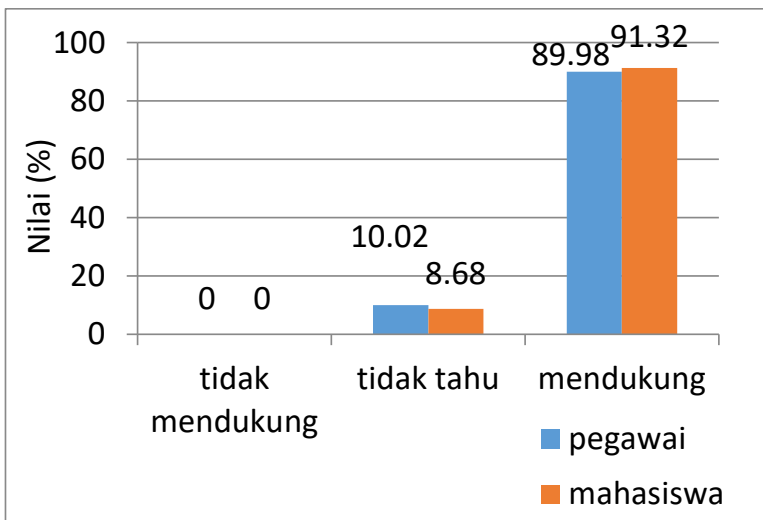

Gambar 43. Grafik perbandingan akumulasi persentase rata-rata jawaban responden pegawai dengan mahasiswa.

Dari grafik pada Gambar 43 menunjukkan bahwa persentase rata-rata jawaban responden pegawai hampir sama dengan persentase rata-rata jawaban responden mahasiswa dengan selisih persentase yang mendukung sebesar $1.34 \%$. Sehingga dapat disimpulkan bahwa dari responden pegawai dan responden mahasiswa setuju dengan usulan sistem ini.

\section{KESIMPULAN DAN SARAN}

\section{A. Kesimpulan}

Berdasarkan hasil penelitian yang telah dilakukan dapat ditarik beberapa kesimpulan sebagai berikut:

1. Sistem pelaporan monitoring spektrum frekuensi radio memiliki fitur diantaranya dapat mengelola admin (lihat, tambah, rubah, hapus), mengelola kelas emisi (lihat, tambah, rubah, hapus), mengelola kelas stasiun (lihat, tambah, rubah, hapus), mengelola kelas emisi (lihat, tambah, rubah, hapus), import data perizinan, mengelola keterangan dan data observasi pita frekuensi, pengukuran radio siaran, pengukuran televisi siaran, monitoring stasiun dinas tetap/bergerak (lihat, tambah, rubah, hapus), membuat laporan dan rekapitulasi pertitik lokasi, per-hari, per-minggu, perbulan, per-tiga bulan, per-enam bulan dan per-tahun.

2. Dalam pembangunan sistem pelaporan monitoring spektrum frekuensi radio dilakukan dengan menggunakan 6 tahapan, diantaranya pengumpulan data, studi literatur, perancangan sistem, coding / implementasi dan pengujian. Sistem ini dibangun dengan bahasa pemrograman HTML dan PHP, menggunakan codeigniter sebagai framework-nya, MySql sebagai server database-nya dan wamp server sebagai server local-nya.

3. Dari hasil pengujian dengan berbagai skenario yang dijalankan untuk menguji sistem berdasarkan fitur-fitur yang terdapat pada sistem pelaporan monitoring spektrum frekuensi radio menunjukkan bahwa sistem sudah berjalan sesuai dengan yang diharapkan tanpa adanya error pada sistem. Berdasarkan hasil kuisioner dapat disimpulkan bahwa sebesar $89.98 \%$ responden dari pegawai dan sebesar $91.32 \%$ responden dari mahasiswa setuju dengan usulan sistem ini.

\section{B. Saran}

Terdapat beberapa saran untuk dapat membuat sistem ini menjadi lebih baik pada waktu yang akan datang, diantaranya:

1. Untuk pengembangan sistem ini dapat ditambahkan fitur untuk mengolah beberapa kegiatan lagi seperti pengukuran karakteristik frekuensi radio, pengukuran karakteristik radio siaran, pengukuran karakteristik stasiun radio dan pengukuran karakteristik radio FM.

2. Menambahkan fitur remote access sehingga sistem ini dapat diakses dari jarak jauh.

\section{DAFTAR PUSTAKA}

[1] S. Wahyuningsih, "Analisis Kendala Perizinan Spektrum Frekuensi Radio untuk Radio Komunitas Constraints Analysis of the Radio Frequency Spectrum Licensing for Community Radio," Bul. Pos dan Telekomun, vol. 12, no. 53, pp. 29-38, 2014.

[2] Erfiani, B. I. Tambubolon, dan Heriyanto, "Data Statistik Direktorat Jenderal Sumber Daya dan Perangkat Pos dan Informatika (Ditjen SDPPI), Semester-2 Tahun 2014," Postel.go.id, vol. 1, p. 246, 2014. 
[3] D. Wahyugi, "Pengembangan Sistem Informasi Pelaporan Monitoring Dan Evaluasi Badan Perencanaan Pebangunan Daerah Kabupaten Bengkulu Utara Berbasis Web," Tugas Akhir S1 Univ. Atma Jaya Yogyakarta, pp. 1-15, 2013.

[4] T. W. Adinugroho dan Krisnawati, "Sistem Pelaporan Terpadu Berbasis Web Pada Dinas Kesehatan Kabupaten Sukoharjo," Naskah Publ. Sist. Inf. STMIK AMIKOM, Yogyakarta, 2015.

[5] Y. Amadatu, "Pengembangan Aplikasi Pelaporan Data
Operasional Puskesmas Berbasis Web," Tugas Akhir S1 Progr. Stud. Tek. Inform. Univ. Atma Jaya Yogyakarta, 2010.

[6] M. Z. Hamidi, S. E. Anjarwani, dan I. W. A. Arimbawa, "Rancang Bangun Sistem Informasi Praktik Kerja Lapangan Pada Program Studi Teknik Informatika Universitas Mataram Menggunakan Extreme Programming," Journal of Computer Science and Informatics Engineering (J-Cosine), vol. 1, no. 1, 2017. 